\title{
Diversity and pathogenicity of Botryosphaeriaceae on declining Ostrya carpinifolia in Slovenia and Italy following extreme weather conditions
}

\author{
Barbara Piškur ${ }^{1}$, Draginja Pavlic ${ }^{2}$, Bernard Slippers ${ }^{3}$, Nikica Ogris ${ }^{1}$, Giorgio Maresi ${ }^{4}$, Michael \\ J. Wingfield ${ }^{2}$ and Dušan Jurc ${ }^{1}$
}

(1) Department of Forest Protection, Slovenian Forestry Institute, Večna pot 2, 1000 Ljubljana, Slovenia.

(2) Department of Microbiology and Plant Pathology, Forestry and Agricultural Biotechnology Institute (FABI), Centre of Excellence in Tree Health Biotechnology, Faculty of Natural and Agricultural Sciences, University of Pretoria, Pretoria, 0002, South Africa.

(3) Department of Genetics, Forestry and Agricultural Biotechnology Institute (FABI), Centre of Excellence in Tree Health Biotechnology, Faculty of Natural and Agricultural Sciences, University of Pretoria, Pretoria, 0002, South Africa.

(4) FEM-IASMA, Centre for Technology Transfer, Via E. Mach 1, 38010 San Michele all'Adige, $\mathrm{TN}$, Italy.

Barbara Piškur

Email: barbara.piskur@gozdis.si

\begin{abstract}
Unusual and extensive dieback of European hop hornbeam (Ostrya carpinifolia) has been observed in western Slovenia and northern Italy in recent years, when extreme drought and higher temperatures were recorded. A preliminary study identified Botryosphaeria dothidea as a potential causative agent of the dieback. Further characterization of intra- and interspecies diversity of Botryosphaeriaceae collected from $O$. carpinifolia and other tree species in the affected area was achieved based on anamorph morphology, sequence data from the ITS rDNA and EF1- $\alpha$, PCRRFLP analysis and AFLP profiles. The majority of the isolates analyzed were identified as $B$. dothidea, and in vitro pathogenicity tests re-confirmed the fungus to be an important cause of the disease. Insight into the B. dothidea population, diversity based on AFLP markers indicates that the dieback observed in $O$. carpinifolia is probably associated with a heterogenous population of $B$. dothidea, which emerged from a latent state in response to changed climate conditions. Isolates with Dothiorella-like conidia were also identified during the survey, but these were collected more rarely and appear to represent undescribed species. Isolates from Dothiorella genus expressed low pathogenicity in pathogenicity tests and proved no impact on the pathogenic ability of $B$. dothidea.
\end{abstract}

\section{Introduction}

The European hop hornbeam, Ostrya carpinifolia Scop. (Betulaceae) is a southern European species, found on dry and degraded sites, in warm, sunny spots, and it is considered resistant to drought. These characteristics make $O$. carpinifolia an important pioneer species. This tree species is the autochthonous in the western karst parts of Slovenia named Kras (Kotar and Brus 1999) and in both the Alps and the Apennines in Italy, where this study was conducted. During the course of the last decades, $O$. carpinifolia has invaded vast areas of abandoned agricultural land, and it is regarded as an ecologically and economically valuable foundation for future forests. 
O. carpinifolia is known to be resistant to various diseases (Kotar and Brus 1999), but an unusual dieback has been observed in Slovenia since 1997. Especially extensive damage and high mortality occurred in 2003, when unusual weather conditions and extreme drought were experienced (Jurc et al. 2006). The disease occurred patchily throughout Slovenian Submediterranean forests (approximately 76,000 ha), where hop hornbeam is present over approximately $60 \%$ of the area. The dieback was noted in about $90 \%$ of the hop hornbeam range, and severe dieback was reported in $26 \%$ of the area (Zafran et al. 2006). The intensive dieback of hop hornbeam is considered a major threat to the reforestation of the Slovenian Submediterranean karst. In Italy, damage due to cankers on branches and stems was reported in 2001 in Province of Trento during Forest Tree Damage Monitoring (FTDM) surveys (Salvadori et al. 2002). In subsequent years, cankers were observed in declining Ostrya wood in Friuli, and they were also recorded in Lombardy and the Apennines, but not related to dieback symptoms (Maresi, personal observation).

Necrotized bark on branches and trunks is the first visual symptom of the disease. The necrosis can spread rapidly throughout the whole trunk and branches of the tree, which subsequently die. Alternatively, the disease ceases to spread and perennial cankers form in the following years (Jurc et al. 2006). Ascomata of Botryosphaeria dothidea (Moug.) Ces. \& De Not. were observed in the dead bark of $O$. carpinifolia in the winter, and conidiomata of the anamorph Fusicoccum aesculi Sacc. were seen during the growing season (Jurc et al. 2006).

Members of the Botryosphaeriaceae produce asci and ascospores in pseudothecia (teleomorph). Their conidia produced in conidiomata are either pigmented and Diplodia-like or hyaline and Fusicoccum-like (anamorph). This fungal family has had a confusing taxonomic history, where names were initially linked to hosts and based on morphological characteristics. The emergence of DNA-based phylogenetic inference has allowed for a more natural classification of the Botryosphaeriaceae (Crous et al. 2006; Slippers et al. 2004). The teleomorphs of species in this group are rarely observed in nature or under laboratory conditions, and they consequently have little taxonomic value due to overlapping morphological characteristics (Slippers et al. 2004). Anamorph morphology, usually adopted to identify species of Botryosphaeriaceae, is also unable to resolve closely related species (Denman et al. 2000; Slippers et al. 2004). Comparisons of DNA sequences for various gene regions have led to re-evaluation of the Botryosphaeriaceae, and numerous new genera and species have been proposed (Crous et al. 2006; Denman et al. 2000; Pavlic et al. 2009; Phillips et al. 2005, 2008; Slippers et al. 2004, 2005a, 2007).

Species of the Botryosphaeriaceae have a wide global distribution on virtually all woody hosts examined to date (Burgess et al. 2005, 2006; Ma et al. 2001a; Mohali et al. 2006, 2007; Pavlic et al. 2007; Slippers et al. 2005a, 2007; Slippers et al. 2005b; Slippers and Wingfield 2007; Taylor et al. 2005). Different species of Botryosphaeriaceae can be isolated from diseased and healthy tissues of the same host (Mohali et al. 2006; Pavlic et al. 2007; Slippers and Wingfield 2007). Endophytic isolates obtained from healthy material have been shown to cause disease symptoms in greenhouse trials (Pavlic et al. 2007). Many of these species are known as opportunistic pathogens with a latent endophytic stage, causing disease symptoms on stressed plants (Slippers and Wingfield 2007; Swart and Wingfield 1991). Pathogenic activity of the Botryosphaeriaceae, as latent opportunistic pathogens, is expected to increase due to climate changes (Desprez-Loustau et al. 2006; Slippers and Wingfield 2007). Extremely dry weather conditions are believed to provoke these quiescent facultative parasites, living in dead parts or as latent endophytes in living tissues to cause disease (Desprez-Loustau et al. 2006).

The study was conducted following preliminary surveys showing that $B$. dothidea was connected to dieback of $O$. carpinifolia in Slovenia (Jurc et al. 2006). Additional investigation has revealed further diversity and potentially other Botryosphaeriaceae that might be involved in the disease. The primary aim was to consider whether the disease observed on O. carpinifolia in Slovenia and Italy 
is due to a recently introduced pathogenic species and alternatively whether this is associated with a native population of opportunistic pathogens induced to cause disease due to altered environmental factors. To achieve this goal, intra- and interspecies diversity of Botryosphaeriaceae associated with dieback of $O$. carpinifolia and other tree species in Slovenia and Italy was characterized. This was accomplished via analyses of sequence data for the ITS rDNA and translation elongation factor 1- $\alpha$ (EF1- $\alpha)$, PCR-RFLP and AFLP profiles, morphological characteristics and pathogenicity tests.

\section{Materials and Methods}

\section{Isolates}

The majority of isolates included in this study were obtained during a 2005 and 2006 disease survey undertaken in the western part of Slovenia (Kras) and including O. carpinifolia, Acer platanoides L., Juniperus communis L. and Cotinus coggygria Scop. trees. The isolates from Italy were obtained in the provinces of Trento and Bologna in 2006. Isolates were taken from necrotic bark, dead branches and from asymptomatic tissues. Healthy tissues were washed in tap water and treated with more concentrated disinfecting solutions comparing with diseased and more degraded tissues. One-millimeter-wide strips were excised from the margins of the necrotic tissue and surface disinfected by submerging for $3 \mathrm{~min}$ in commercial bleach $(\mathrm{NaOCl}, 6 \%$ free $\mathrm{Cl})$, diluted to contain $3 \%$ active chlorine. Strips were cut into segments $\left(\sim 1 \mathrm{~mm}^{2}\right)$ and blotted dry. Asymptomatic branches were washed in running tap water for $2 \mathrm{~h}$ prior to isolation. Bark strips $\left(\sim 20 \mathrm{~mm}^{2}\right)$ were excised and disinfected for $1 \mathrm{~min}$ in $6 \%$ commercial bleach. Segments $(\sim 1 \mathrm{~mm} 2)$ of the disinfected strips were placed on 2\% malt extract agar (MEA; 2\% malt extract, 1.5\% agar; Biolife) and incubated at $24^{\circ} \mathrm{C}$. Some isolates were obtained directly from the perithecia embedded in the diseased bark. All isolates used in this study were deposited in the culture collection (CMW) of the Forestry and Agricultural Biotechnology Institute (FABI), University of Pretoria, South Africa (Table 1).

\section{DNA extraction}

DNA was extracted from pure cultures of all isolates using PrepMan ${ }^{\circledR}$ Ultra Sample Preparation Reagent (Applied Biosystems). The nucleic acid concentrations in DNA extracts were determined with an ND-1000 Spectrophotometer (NanoDrop Technologies). The original DNA extracts were diluted with distilled water to concentrations of $30-60 \mathrm{ng} / \mu \mathrm{l}$ and used in further reactions unless otherwise specified.

\section{PCR amplification}

The amplification of the ITS rDNA region, comprising the 3 'end of the $18 \mathrm{~S}$ rRNA gene, the first internal transcribed spacer ITS1, the 5.8S rRNA gene, ITS2 and the 5'end of the 26S rRNA gene, was performed with the primer pair ITS1 (5'-TCCGTAGGTGAACCTGCGG-3') and ITS4 (5'TCCTCCGCTTATTGATATGC-3') (White et al. 1990). A part of elongation factor $1-\alpha(E F 1-\alpha)$ was amplified using the primer pair EF-Af (5'-CATCGAGAAGTTCGAGAA-3') and EF-Br (5'CRATGGTGATACCRCGCTC-3') (Sakalidis 2004). The PCR mixtures and cycling parameters were as described by Slippers et al. (2004). The PCR products were separated in a $1 \times$ Tris-acetate EDTA (TAE) 1.5\% agarose gel (Agarose LE, Roche) with ethidium bromide added to a final concentration of $5 \times 10^{-4} \mu \mathrm{g} / \mathrm{ml}$. The bands were visualized under UV light, and the sizes of PCR products were estimated using molecular weight marker $\left(\mathrm{O}^{\prime}\right.$ Gene Ruler ${ }^{\mathrm{TM}} 100$ bp DNA Ladder Plus, Fermentas).

Table 1. Fungal isolates subjected to anamorph morphology characterization, DNA sequence analyses, phylogenetic studies, PCR-RFLP, pathogenicity trials and AFLP analyses. 


\begin{tabular}{|c|c|c|c|c|c|c|c|c|c|c|}
\hline \multirow[t]{2}{*}{ Colbure $\mathrm{Na}_{0}{ }^{2 *}$} & \multirow[t]{2}{*}{ Other No } & \multirow[t]{2}{*}{ Mencry } & \multirow[t]{2}{*}{ Bos } & \multirow[t]{2}{*}{ locersoa } & bolocod fromen & Collocos & PCR-RFIP & AFL'P & ESTAL acos & ssioa $\mathrm{Na}^{2}{ }^{2}$ \\
\hline & & & & & & & & & $\overline{\pi s}$ & EF-1 $\alpha$ \\
\hline CSW 25638 & APK $S n$ & B athisa & A prasiaviles & Gorjesta, s1 & Nexrobined toxk & D. Juon oys & n & - & & \\
\hline CMW 2s6ss & $A P K 4 / 2$ & B dotica & A plasumiles & Grjesta, sl & Norrotined taxk & D. Jron oys & 1 & - & FM955373 & PM9554): \\
\hline CSPW 26223 & APK $3 / 3$ & B dutika & A platawites & Grjesta, st & Norrobind toxk & D. Jron oys & 1 & - & FMS5532 & FM955406 \\
\hline CMW 25690 & APK $1 / 4$ & B dutika & A phasustiles & Grjesta, st & Nerrotined taxk & D. Juron Oys & n & - & FM953374 & \\
\hline CaW 2569 & APK $2 / 4$ & B dotika & A phasaviles & Grjesta, st & Narotined taxk & D. Jron oys & n & - & & \\
\hline CMW 25692 & CST 13 & B dotika & c. cosegis & Gorjesta, S1 & $\begin{array}{l}\text { Deat latk of cat } \\
\text { Beach }\end{array}$ & D. Juron oys & $\mathbf{n}$ & $\cdot$ & FAs5535 & FM95549: \\
\hline CMW 25693 & CST $2 / 3$ & E dotika & C. Cogsis & Grijesta, SI & $\begin{array}{l}\text { Deat lark of out } \\
\text { bendich }\end{array}$ & D. Juon oys & n & - & & \\
\hline CMW 25686 & OPIT 17 & R dotiza & a capingitas & Css Dusce, $\pi$ & Narrobiad toxk & G. Maresi & 1 & & PM955381 & FM9554]: \\
\hline CSPW 26221 & OPIT 18 & E dutiza & a. capingatis & Cass Dusce, $\pi$ & Norrotined toxk & G. Mhesi & n & & FM955362 & \\
\hline CMW 35222 & OEח 24 & R dotika & a carpingetis & $\operatorname{Nami} \pi$ & Geen buxk & G. Muresi & n & - & FM955376 & FMS554tC \\
\hline CMW $\$ 2220$ & OPIT 3 & A dotika & a coopingeds & S. MAcleie, it & Narrociad toxk & G. Maresi & n & & PM95530 & \\
\hline CMW 25687 & OET 25 & B dutiza & a capingess & S. Melele IT & Geen bxk & G. Mursi & n & - & & \\
\hline CSW 25694 & OPG $s n$ & E dotika & a capingats & $\begin{array}{l}\text { Coopasta } \\
\text { Geapina st }\end{array}$ & Narocined taxi & D. Juon Oyis & n & $\cdot$ & & \\
\hline CMW 25695 & OPG 61 & B botika & a. cospingeds & $\begin{array}{l}\text { Coopaista } \\
\text { Ginaja sI }\end{array}$ & Narocinad tax & D. Juon Oyis & n & $\cdot$ & & \\
\hline CMW 25698 & OPG $m$ & E dotika & a capingeds & $\begin{array}{l}\text { Coopoista } \\
\text { Geaja SI }\end{array}$ & Narociand taxk & D. Juon oys & 1 & $\cdot$ & FM95539 & FM95541: \\
\hline CMW 2569 & OPG $\$$ & E dotika & a capingess & $\begin{array}{l}\text { Coopusta } \\
\text { Gempina S1 }\end{array}$ & Narrotined baxk & D. Juon oys & n & & & \\
\hline CSW 25698 & OPG $3 / 2$ & E dotika & a capingats & $\begin{array}{l}\text { Coopusta } \\
\text { Ginipa s1 }\end{array}$ & Narotiond taxk & D. Juan Oys & n & $\cdot$ & & \\
\hline CSF 2569 & OPK $1 n$ & E dotika & a capinjotid & Kai, SI & Norrociond taxk & D. Juon oys & n & & & \\
\hline CSTW 26700 & OPK $2 n$ & E dotika & a. capinizals & $\mathrm{Kati}, \mathrm{sl}$ & Narociad taxk & D. Jron oys & n & - & & \\
\hline CSW 25700 & OPK $3 n$ & R dutika & a capingets & $\mathrm{Kati}, \mathrm{SI}$ & Nexrotiand taxk & D. Jron oys & n & - & & \\
\hline CSTW 2570 & OPK 61 & B dutika & a capinjols & $\mathrm{Kat}, \mathrm{SI}$ & Narociond toxk & D. Juon oys & 11 & & & \\
\hline CSW 25703 & OPK ton & E dotika & a. capinjzedis & $\mathrm{Kat}, \mathrm{SI}$ & Norrotinat taxk & D. Juron Oyis & n & & & \\
\hline Crow 25704 & OPK $1 / 2$ & B dutiza & a capinjolis & Kan, sl & Narobinat taxk & D. Juon ogis & 1 & - & & \\
\hline CMW 25705 & OPK $2 n$ & B dutika & a capinjodis & Kat, sl & Narocinad taxk & D. Jron oys & 1 & - & & \\
\hline CrW 25706 & OPK $4 / 2$ & B dutika & a cappinglatis & $\mathrm{Kan}, \mathrm{SI}$ & Nexrotiond taxk & D. Jron oys & 1 & - & & \\
\hline CSPW 25700 & OPK $S: 2$ & B a datika & a capingelis & $\mathrm{K}=2, \mathrm{SI}$ & Norrociand taxk & D. Jron oys & n & - & & \\
\hline CMW 25708 & OPK $72 \mathrm{~A}$ & B dotika & a capingeds & $\mathrm{K}=2, \mathrm{ST}$ & Norrotiond taxk & D. Juon oys & n & - & & \\
\hline Carw 2570 & OPK $9 / 2$ & B dutiea & a capinjots & Kan, SI & Nerrotiond toxk & D. Juon oys & 1 & - & & \\
\hline CMW 25710 & OPERK 1 & E dotika & a capingats & Kai, st & 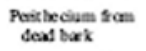 & D. Juon oys & l & $\cdot$ & FM955378 & FMs554: \\
\hline CMW 25711 & OPERO 4 & E dotika & a cappinjolis & Opatge Seb, sI & 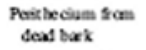 & D. Juon Oys & 11 & - & & \\
\hline CSF 25712 & OPERO 5 & E dothisa & a cappinjolis & Opatse Sebo, s1 & 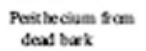 & D. Juon oys & $n$ & $\cdot$ & & \\
\hline CSPW 25713 & OPERO 6 & E dotika & a cappinjodis & Opate Seb, s1 & $\begin{array}{l}\text { Pastreciue from } \\
\text { dead txik }\end{array}$ & D. Jron oys & n & $\cdot$ & & \\
\hline CSW 2574 & OPO $2 n$ & E duthisa & a capinjigtis & Opate Sebo, s1 & Necrocind taxk & D. Jron oys & n & - & & \\
\hline CSF 25715 & OPO $4 n$ & B actika & a cappinjolis & Opasje Sebo, S1 & Narotimad taxk & D. Juon Oys & n & & & \\
\hline CSTW 25716 & $\mathrm{OPO} 3 / 2$ & B dutiza & a capingals & Opase Sebo, sl & Narrotiond taxk & D. Juron Oyss & $\mathbf{n}$ & & & \\
\hline Carw 257 & OPO $1 / 1$ & E dotiza & a capinizdis & Opase Sebo, s1 & Norrotiand toxk & D. Jron oys & n & & & \\
\hline CSW 25718 & OPP $1 n$ & E Gotika & a capingeds & Podzorie SI & Narociand taxk & D. Juron Oys & 1 & - & & \\
\hline CSW 2579 & OPP 61 & E dotika & a capingatdis & Podzaje SI & Nearotinad taxk & D. JuroN Oys & n & $\cdot$ & & \\
\hline CSTW 2570 & OPP $6 / 2$ & B dutiza & a capinjotis & Podzariess & Norrotined taxk & D. Jron oys & $n$ & & & \\
\hline CMW 25721 & OPR $w_{1}$ & B dotika & a cappingkdis & Ravaje, SI & Narotiond Daxk & D. Jron Ogis & n & - & & \\
\hline CSTW 2572 & OPR 31 & E dotika & a cappinjols & Ravaje, SI & Narrotiond taxk & D. Jron oyss & n & - & & \\
\hline CST 25723 & OPR 51 & B dotika & a capingigla & Ravaje, sl & Norrotined toxk & D. Jron ogis & n & - & & \\
\hline CrW 25724 & OPR 61 & B duthe a & a capingeds & Ravaje, SI & Narotiond toxk & D. Jron Oys & n & - & & \\
\hline Carw 25723 & OPR $q_{11}$ & B dotiza & a capingigla & Ravaje, SI & Nowrotiand toxk & D. Jron Oys & n & - & & \\
\hline CSF $257 x$ & OPR $4 \mathrm{x}$ & E dotked & a capingzalis & Ravaje, SI & Norrotiond taxk & D. Juron Oyis & n & $\cdot$ & & \\
\hline CST 2572 & OER Y/AI & R dutika & a capinzedia & Ravaje SI & Gees Bax & D. JroN Oys & n & - & & \\
\hline CSW 25728 & OPS $1 n$ & E dotika & a capingatsis & Soblorec, SI & Norrotiond toxk & D. Jron oys & $n$ & - & & \\
\hline Carw 2572 & OPS $4 / 1$ & B autiea & a. capinjzdis & saborec SI & 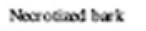 & D. Jron ogis & $n$ & - & & \\
\hline CSW 25730 & OPS 61 & R dotika & a capingets & Solowec, SI & Narrotiand taxk & D. JroN oys & n & - & & \\
\hline CSW 2573! & OPS $5 / x$ & E dotika & a. cappinjods & Socbovec, SI & Necrotinad taxk & D. Juron Oyis & n & $\cdot$ & & \\
\hline CSF 25732 & OPS ICOX & E dotika & a. cappinjoctis & Soubrec, sl & Narrotined baxk & D. Jron oys & n & $\cdot$ & & \\
\hline CMW 36224 & OES $4 / 1$ & B dotiza & a capingeds & Sabovec, SI & Geen Dxx & D. Jron oys & n & - & FMss537 & PM9554! \\
\hline CSF 25733 & OES $8 n$ & B dotika & a capingatas & Soblorec, SI & Gees Bark & D. Juron Oyis & n & $\cdot$ & & \\
\hline CSW 25734 & OPERSG 1 & B autiza & a capingeds & Sx Goa SI & 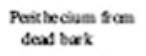 & D. Jron oys & $\mathbf{n}$ & $\cdot$ & & \\
\hline CSW 2573 & OPERSG 2 & E dotika & a capingets & Sx Goa sl & 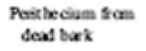 & D. Jron oys & 11 & - & & \\
\hline Car 25736 & OPSG $1 n$ & B dotiza & a. capingats & Sx Goa sl & Nocroefind toxk & D. Jron oys & n & - & & \\
\hline Carw 2573 & OPSG $4 / 1$ & B dutika & a capinjolis & Sx. Goa st & Narotiond taxk & D. Juron Oyis & n & $\cdot$ & & \\
\hline CMW 25738 & OPSG $2 / 2$ & B dotike a & a capingiglis & sx Goa st & Narotiand taxk & D. JroN Oyss & n & - & & \\
\hline CSOW 2573 & OPSG $3 / 2$ & B. deatiliod & o. earpingosis & Sx Goa SI & Necrocizad tax & D. JuoN. Oyss & n & - & & \\
\hline CONW 25740 & OPSG $\$ 2$ & B. deatilod & 0. carpingosis & Sx. Goea SI & Necrotized tax & D. Juon. Ozis & n & - & & \\
\hline CrW 2874 & OET $2 B$ & Dostion $M$ sp. & o. carpinisosis & Locher, IT & Groes bat & G. Muresi & III & & PSDs5386 & FM955418 \\
\hline CMW 25744 & OPT 1 & Dotiba Ma sp. & 0. arpinjбos & $\begin{array}{l}\text { Moxe Maxia } \\
\pi\end{array}$ & Necrosion taxt & G. Maresi & 1 & & F)Es5387 & FMS55419 \\
\hline CSW 25745 & opm 11 & Dothor $\mathrm{Ma}$ sp. & 0. carpingosis & Ponsexda $\pi$ & Necrocizal tax & G. Mhesi & 1 & & & \\
\hline CMW 23746 & OPT 13 & Dostion $\mathrm{Ma}$ sp. & o. сатpingos & Ponsda $\pi$ & Necration tax & G. Muresi & 1 & & PSEs3383 & FM1s430 \\
\hline Corw 2574 & OETT 22 & Dostion $M$ sp. & 0. аarpingosia & Ponexda $\pi$ & Groes bax & G. Maresi & 1 & & & \\
\hline CSW 25743 & OPT 2 & Destion $\mathrm{a}$ sp. & o. carpingosis & S. Mathele, IT & Necrosion bat & G. Muesi & 1 & & & \\
\hline Carw 2574 & Opr 6 & Dothor ma sp. & 0. carping6sis & S. Mschele, IT & Necrociad tark & G. Mhesi & 1 & & & \\
\hline CMW 25750 & OET $D$ & Destion ma sp. & o. arping;osia & S. Mathele, IT & Groen bats & G. Mhresi & 1 & & PSEs5335 & PM154 \\
\hline CMW 2575r & $\operatorname{cst} 32$ & Dothorem sp. & C. cosogris & Gogenta SI & Deal baxih & D. Jron. Ozis & 1 & & PNoss384 & FM9554I6 \\
\hline CYW $2575 z$ & RRINPK $1 n$ & Dostion ma sp. & f. commanis & $\mathrm{Kan}, \mathrm{s} \mathbf{S}$ & Deal beaxh & D. JuoN. Ozis & 1 & & FAss333 & FM955415 \\
\hline CNW 3636r & OPK $u x$ & Dothiow $3 \mathrm{sp}$ sp. & 0. сатpingos & $\mathrm{Kan}, \mathrm{SI}$ & Necrotiod tax & D. Jron. Ozis & 1 & & F⿻上53399 & FM955421 \\
\hline CSW 2330 & OPP $4 / 1$ & Dostion Ma sp. & o. carpingosis & Polacaje $\$ 1$ & Neacciciod tax & D. JroN. Oyjs & 1 & & PSEs5390 & PM955422 \\
\hline CNW 28753 & OPP $9 / x$ & Destion ma sp. & 0. carping6sis & Polacaje S1 & Necrocisol tax & D. JuoN. Oyis & 1 & & FSEs5391 & FM955423 \\
\hline CNW 25754 & OPR $8 / 2$ & 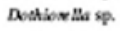 & 0. arpingos & Ravaje, S1 & Necrociad tax & D. JroN. Oyss & 1 & & FSEss392 & FM1955424 \\
\hline CSP 25795 & OPS $7 / \mathrm{x}$ & Dottion $\mathrm{Ma}$ sp. & 0. сатping6s & Subovec SI & Necrotion that & D. Juon. Ozis & 1 & & & \\
\hline
\end{tabular}




\section{PCR-RFLP analysis}

The ITS rDNA PCR-RFLP analyses were performed for all isolates collected in this study. For PCR-RFLP analysis, the ITS rDNA PCR products were digested with the restriction endonuclease $\mathrm{CfoI}$ (Roche Diagnostics). The reaction mixture contained 10 or $12 \mu \mathrm{l}$ of PCR product, $0.3 \mu \mathrm{l}$ of 10 $\mathrm{U} / \mu \mathrm{l} \mathrm{CfoI}, 2 \mu \mathrm{L}$ of matching enzyme buffer and an adequate volume of distilled water to reach the final volume of $15 \mu \mathrm{l}$. Restriction digests were performed at $37^{\circ} \mathrm{C}$ for $12 \mathrm{~h}$. The fragments were separated on a 3\% agarose gel as previously described for PCR products. The resulting restriction profiles were compared with those of Slippers et al. (2007).

\section{Morphological characterization}

Selected isolates, representing different localities, hosts, morphological characteristics and RFLP profiles, were transferred onto $2 \%$ water agar (WA; Biolab) with sterilized pine needles and incubated at $25^{\circ} \mathrm{C}$ under near-UV light, to induce sporulation. Released conidia were collected and mounted in $85 \%$ lactic acid on microscope slides. Slides were examined, and spores photographed and measured under a light microscope with an Axiocam digital camera and accompanying software (Carl Zeiss Ltd).

\section{DNA sequencing and analyses}

The ITS rDNA and EF1- $\alpha$ regions of selected isolates, representing different localities, hosts and morphological characteristics, were sequenced (Table 1). The PCR products were cleaned using Centri-Sep Spin Columns (Applied Biosystems) with Sephadex ${ }^{\circledR}$ G-50 (Sigma-Aldrich) or using the High Pure PCR Product Purification Kit (Roche Diagnostics). Sequencing was performed in both the forward and reverse directions using the same primers as for the PCR. The ABI PRISMTM Big Dye Terminator Cycle Sequencing Ready Reaction Kit (Perkin-Elmer) was used for sequencing reactions according to the manufacturer's instructions. Sequencing reactions were run on an ABI PRISM $3100^{\mathrm{TM}}$ automated DNA sequencer (Perkin-Elmer).

All sequences were checked manually, and indistinct nucleotides were clarified by comparing sequences from both strands. Sequence data were analyzed using Chromas Lite Version 2.01 (Technelysium Pty Ltd) and aligned with ClustalW, available within the program pack MEGA Version 4.0.2 (Tamura et al. 2007).

Phylogenetic analysis was conducted in MEGA 4.0.2 (Tamura et al. 2007). Phylogenetic relationships were estimated using neighbor-joining (NJ) analysis (Saitou and Nei 1987) performed using the maximum composite likelihood method and pairwise deletion options. Bootstrapping (2,000 replicates) was performed to assess the confidence level at each branch. Sequences used for phylogenetic analyses are listed in Tables 1 and 2.

AFLP analyses of genomic DNA from selected $B$. dothidea isolates (Table 1) were performed following the guidelines of Vos et al. (1995). Genomic DNA, ranging in concentration from 50 to $100 \mathrm{ng} / \mu \mathrm{l}$, was cut with the restriction enzymes EcoRI and MseI. Corresponding Eco- and Msespecific oligonucleotide adapters were used in the subsequent ligation step. Preselective amplification was performed with zero-base-addition EcoRI and MseI adapter-specific primers. The success of the preamplification step was checked by electrophoresis on a $1.2 \%$ agarose gel in $1 \times$ TBE buffer $(30 \mathrm{~min}$ at $80 \mathrm{~V})$. Three different primer pair combinations of labeled EcoRI (E) and unlabeled MseI (M) were used for final selective amplifications (M-02/E-AA, M-02/E-AAC and M06/E-ACC). Primer E was 5' labeled with infrared dye (IRDye 700 or IRDye 800, LI-COR). PCR conditions and reaction mixtures were as described by De Vos et al. (2007). An equal volume of loading solution (LI-COR) was added to each selective amplification reaction, followed by 
denaturation at $95^{\circ} \mathrm{C}$ for $3 \mathrm{~min}$. The samples were placed on ice before gel loading. Electrophoresis and detection of AFLP fragments were performed on a LI-COR IR2 (model 4200S) automated DNA analyzer, as described by Myburg et al. (2001). The electrophoresis run parameters were set to $1,500 \mathrm{~V}, 35 \mathrm{~mA}, 35 \mathrm{~W}, 45^{\circ} \mathrm{C}$, motor speed 3 and signal filter 3 . The electrophoresis prerun time was set to $30 \mathrm{~min}$, and the run time was set to $4 \mathrm{~h}$. The Quantar Pro 1.1 Program (KeyGene) was used for gel analysis. Visible and polymorphic AFLP bands were scored as present ' 1 ' or absent ' 0 ' at each position. The statistical program STATISTICA Version 9 (Statsoft, USA) was used to make a dendrogram, using the cluster procedure with unweighted pair-group averages and percent disagreement.

Table 2. Nucleotide sequences obtained from the GenBank nucleotide database and used in phylogenetic analyses.AFLP analyses.

\begin{tabular}{|c|c|c|c|c|}
\hline \multirow[t]{2}{*}{ Fungel species } & \multirow[t]{2}{*}{ bolace } & \multicolumn{2}{|l|}{ Geafienk } & \multirow[t]{2}{*}{ Reserestos } \\
\hline & & ms & EF-1 $\alpha$ & \\
\hline Dotionel.Ms sp & ת. 59 & EU673314 & Eu673281 & Plallye \& al $(2006)$ \\
\hline Dothiorella sp & CAP 187 & Et673313 & Eบ673230 & Plallyp \& al $(x 00)$ \\
\hline Doshionelas sp & CAA $00 S$ & Et673312 & Eบ673279 & Phallipe ex al (2003) \\
\hline Dotiorel.ts monet & Muxos 506 & EF91921 & EF59972 & Taybe es a. (2009) \\
\hline Dothiore Is satall & MUCC 509 & EF91924 & EF594975 & Taybe es a ( 2009$)$ \\
\hline 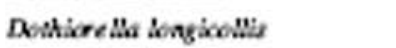 & CAS 122063 & EU140S4 & Eบ144069 & Puric es al (xoos) \\
\hline Doatiorel.ts angion:-1s & CBS 120067 & EU14053 & EU144063 & Pavic \& al $(2003)$ \\
\hline Dothiorel.ts aterios & CAS 119041 & AY 573202 & AY 573222 & Plallipe \& al (2005) \\
\hline 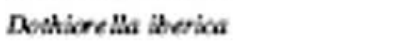 & CAS 113138 & AY573198 & Eบ673278 & Phalles \& al ( 2005,2006$)$ \\
\hline Deationela somertoram & CAS 119038 & AY 53206 & A Y 573223 & Plallipe \& al (2005) \\
\hline D; phas acerive & CAS91073 & EU673315 & Eบ673282 & Plalips $\&$ al $(2003)$ \\
\hline Doutiorel. savmersoram & MN1 6358 Is & AY 533212 & A Yr573235 & Phallipe \& al $(2005)$ \\
\hline Dipbua conz & CAS 24251 & Eบ673317 & EU673284 & Plalipe \& al $(2000)$ \\
\hline Diphas a jagkas & CRS188.87 & E4673316 & E4673283 & Pailipe es al $(2003)$ \\
\hline Sprocermurtivia vitions & CAS 112010 & AY90553 & Ansos56t & Luque es al (2005) \\
\hline Beryoupheria dookida & CNW 8000 & Ar 23699 & A 236398 & Stippret et (2004) \\
\hline Beryosphieria dowiles & CAS 110302 & AY 259092 & A 5573218 & Alves et al (2004), Plallips os al (2005) \\
\hline Beerosphaeria carticis & CRS 119047 & DQ239345 & EtDi7539 & Lacsine of a. (2008), Phallips et a. (2006) \\
\hline Negsicacam parvam & CAS 110301 & AY 259093 & Ars73221 & Alves et al (2004), Fallips os al (2005) \\
\hline Negkicacam mangiferam & CSW 7004 & AY615185 & Doos221 & Buyes \& $\alpha$. (2005). Slippes \& $\alpha$. ( 2005$)$ \\
\hline Nopgricaram lieeim & CAS 110e9s & AY 259091 & A 5573217 & Alves et a. (2004), Plalips \& al (2005) \\
\hline Lavioliphalis cristisona & WAC 12533 & $\mathrm{DQ} \$ 03550$ & DQ10355 & Bupes of $x \cdot(2000)$ \\
\hline Lasialiphalia gorabiensis & CBS 113812 & $\mathrm{DQ} 453392$ & $\mathrm{DQ} 4583 \pi$ & Alves et al (2006) \\
\hline Laximiphatis parsa & CAS 35659 & FF22082 & EF622002 & Alves et al (2008) \\
\hline Lasiodiphodia preaboteotemie & CBS 447.62 & FFQ22031 & EF622000 & Alves et al (2008) \\
\hline Laviadiphalis theobromos & CAS 12413 & $\mathrm{DQ453830}$ & DQ488875 & Alves eta. (2006) \\
\hline Diploda pisn & CRS 393.84 & $\mathrm{DQ} 453395$ & DQ458330 & Alver et al (2006) \\
\hline Diploda a rives & CAS 112555 & AY 259094 & A Y 573220 & Alves et al (2004). Plalips \& al (2005) \\
\hline Diplas a maila & CAS 112553 & AY 259093 & Ars53219 & Alves et al (2004) Plalipe of al (200) \\
\hline Diphoda voraka & CAS 116470 & Et430265 & Eu430267 & Phallex \& al $(2006)$ \\
\hline Spencermartivia vitionds & CAS 11 XOOS & AY90554 & Arsoss3 & Luque es a. (2005) \\
\hline
\end{tabular}

\section{Pathogenicity trials}

Three $B$. dothidea isolates, three isolates representing Dothiorella sp. "A" group and one isolate from the Dothiorella sp. "C" group (Fig. 1) were selected to represent different localities, hosts, morphological and molecular characteristics and used in a pathogenicity trial under laboratory conditions at $24^{\circ} \mathrm{C}$ (Table 1). Two combinations, CMW $25696 \times$ CMW 25751 and CMW $25689 \times$ CMW 25754, representing B. dothidea and Dothiorella sp. "A", respectively, were used to test the synergistic effect of these species on disease development. $O$. carpinifolia cuttings, $35 \mathrm{~cm}$ long with a mid-diameter of around $30 \mathrm{~mm}$ were inoculated. 


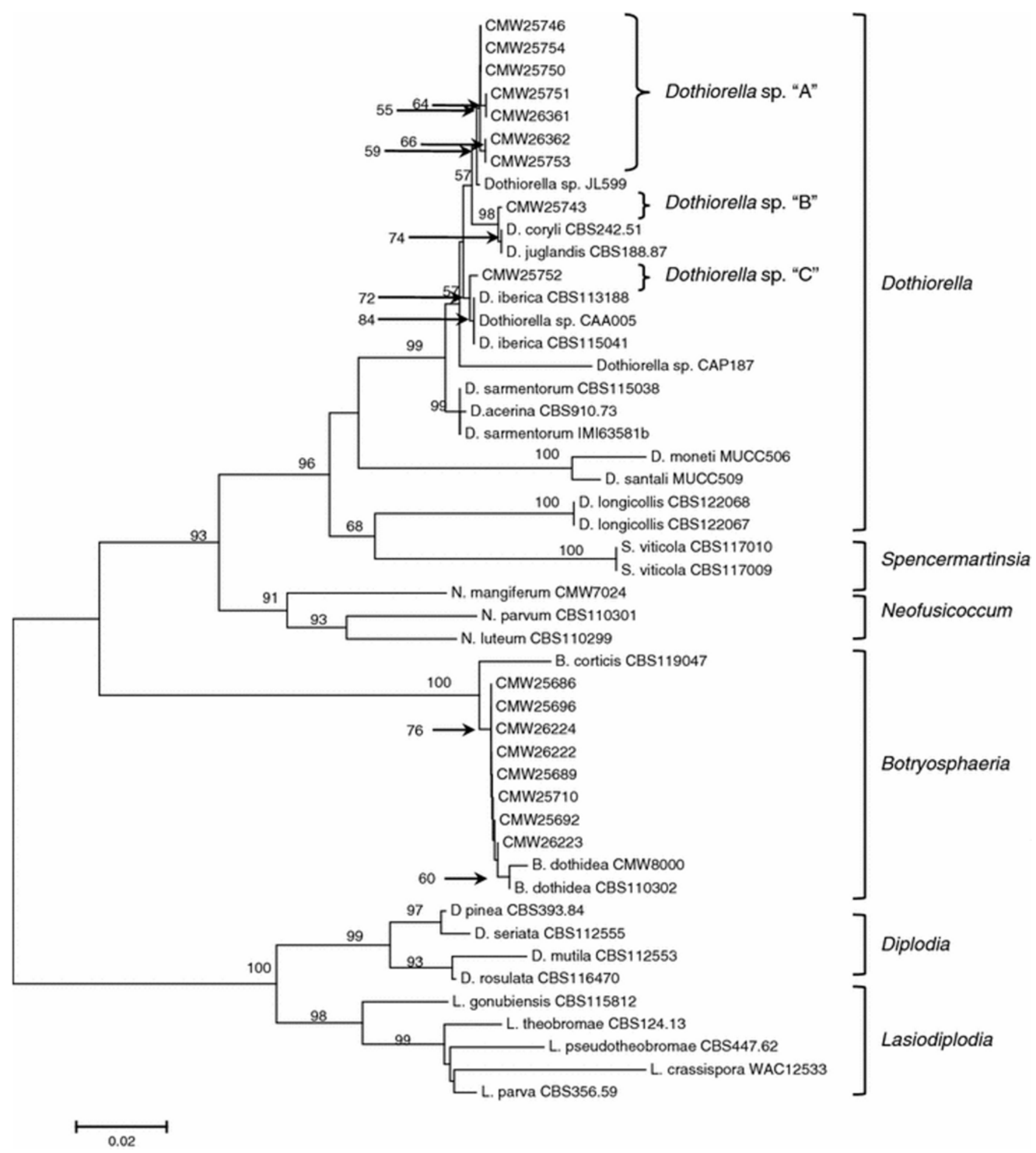

Fig. 1. Phylogenetic tree from combined EF-1 $\alpha$ and ITS rDNA dataset. The tree is unrooted and was constructed with the neighbor-joining method. Bootstrap values $(2,000$ replicates $)$ are indicated at the nodes.

Additionally, the pathogenicity trials were designed to test the relative turgidity of bark as a possible factor that might influence pathogenicity. Therefore, two different trials were performed, named the "humid" and "dry" experiments. In each experiment, ten cuttings were inoculated with each of the selected isolate (one inoculation per cutting), with a combination of the two isolates or with sterile MEA plugs as controls. All cuttings included in pathogenicity tests were harvested at one location in the western part of Slovenia, near Kozina, at $535 \mathrm{~m}$ above sea level, and each cutting was cut from a different tree. 
Inoculations were performed in the late summer (August 2007) with one-week-old fungal cultures grown on MEA at $24^{\circ} \mathrm{C}$. The cuttings were wounded with an $8-\mathrm{mm}$ diameter cork borer to remove the bark. Mycelium plugs ( $8 \mathrm{~mm}$ in diameter) were placed into the wounds with the mycelium surface facing the cambium. For combined inoculations, halves of mycelial plugs of the selected isolates were placed in the same wound. Inoculation points were covered with laboratory film to prevent desiccation and contamination (Parafilm M, Pechiney Plastic Packaging). The "humid" experiment was performed using fresh $O$. carpinifolia cuttings with the upper ends sealed with paraffin and the bottom ends freshly cut and placed in damp vermiculite, supplied with water weekly. In the "dry" experiment, the relative turgidity of the bark was lowered by drying. Inoculated cuttings, with both ends sealed with paraffin, were placed in a plastic bag in a woodpile arrangement with sheets of coarse filter paper between the layers and stored at room temperature. The filter papers were changed every week to ensure constant removal of humidity. The relative turgidity of the bark was determined for each cutting used in both experiments, at the beginning and at the end of the experiment following the method described by Weatherley (1950) and Bier (1959, 1961). Relative turgidity estimates involved the measurement of fresh weight, saturated weight and dry weight of bark samples. The relative turgidity is expressed as the ratio between the amount of water in a fresh bark sample and the amount of water required to saturate the same bark sample.

The pathogenicity was determined by measuring the lengths of lesions after one month. Two randomly selected cuttings representing inoculated isolates or uninoculated controls were selected for fungal re-isolations from the lesion edges. Statistical analyses (Duncan's multiple comparison procedure) were performed with Statgraphics Plus (version 5.1, Statistical Graphics Corp.). The differences between means were determined at a 95\% confidence level.

\section{Results}

\section{PCR-RFLP analysis}

Three different banding patterns were obtained after restriction with $C f o$ I. The restriction profile of the majority of isolates resembled that of $B$. dothidea, as reported by Slippers et al. (2007). The remaining two profiles could not be matched with any of the patterns presented in the previous study (Table 1). The restriction reactions were not successful for a group of isolates, and some of these isolates were selected for further sequence analyses in order to determine their identity.

\section{Morphological and molecular characterization}

Regions approximately 550 (ITS rDNA) and 300 (EF1- $\alpha$ ) base pairs (bp) in length were amplified and sequenced for selected isolates (Table 1). The sequence data for the ITS rDNA regions and EF$1 \alpha$ were combined and used for phylogenetic analyses. All positions containing alignment gaps and missing data were eliminated only in pairwise sequence comparisons. There were a total of 915 positions in the final dataset.

The grouping of isolates included in this comparison was consistent with the analysis performed by Phillips et al. (2008). Isolates obtained during the 2005 and 2006 surveys in Slovenia and Italy were grouped into Botryosphaeria and Dothiorella clades, based on the combined sequence data for the ITS rDNA and EF1- $\alpha$ gene regions (Fig. 1).

All but one of the selected isolates (CMW 25743) formed pycnidia on sterilized pine needles on WA after 2-3 weeks. No teleomorph structures were observed. Based on conidial morphology, including shape, color, septation and size, isolates were separated into two distinct groups. These included those (1) with Diplodia-like conidia that were brown and had one to three septa and conidia becoming pigmented and septate while still attached to conidiogenous cells and (2) those with 
Fusicoccum-like conidia that were hyaline and aseptate. These groupings were consistent with those emerging from the PCR-RFLP profiles and comparisons of the ITS rDNA and EF1- $\alpha$ sequences. Isolates with Fusicoccum-like conidia were identified as $B$. dothidea. These conidia were narrowly fusiform, and some were irregularly shaped with granular contents (average of 150 conidia: $24.1 \times$ $6.0 \mu \mathrm{m})$. Diplodia-like conidia were pigmented, thick-walled and had rounded ends, one of which was usually truncated. Isolates with Diplodia-like conidia fell into the Dothiorella group of the Botryosphaeriaceae, where further divisions were made using DNA sequence comparisons. Isolate CMW 25752 (average of 50 conidia: $25.2 \times 9.6 \mu \mathrm{m}$ ) was grouped close to Dothiorella iberica A.J.L. Phillips, J. Luque \& A. Alves, but it resided a separate clade in the phylogenetic tree based on two DNA regions (Fig. 1). Definitive identification as D. iberica could not be obtained due to discrepancies in the conidial morphology among isolates. Conidia of isolate CMW 25752 were found to have one to three septa (Fig. 2), while D. iberica is reported to have smaller and wider conidia with one septum (Phillips et al. 2005). Consequently, this isolate was not assigned a name and it is referred to as Dothiorella sp. "C".

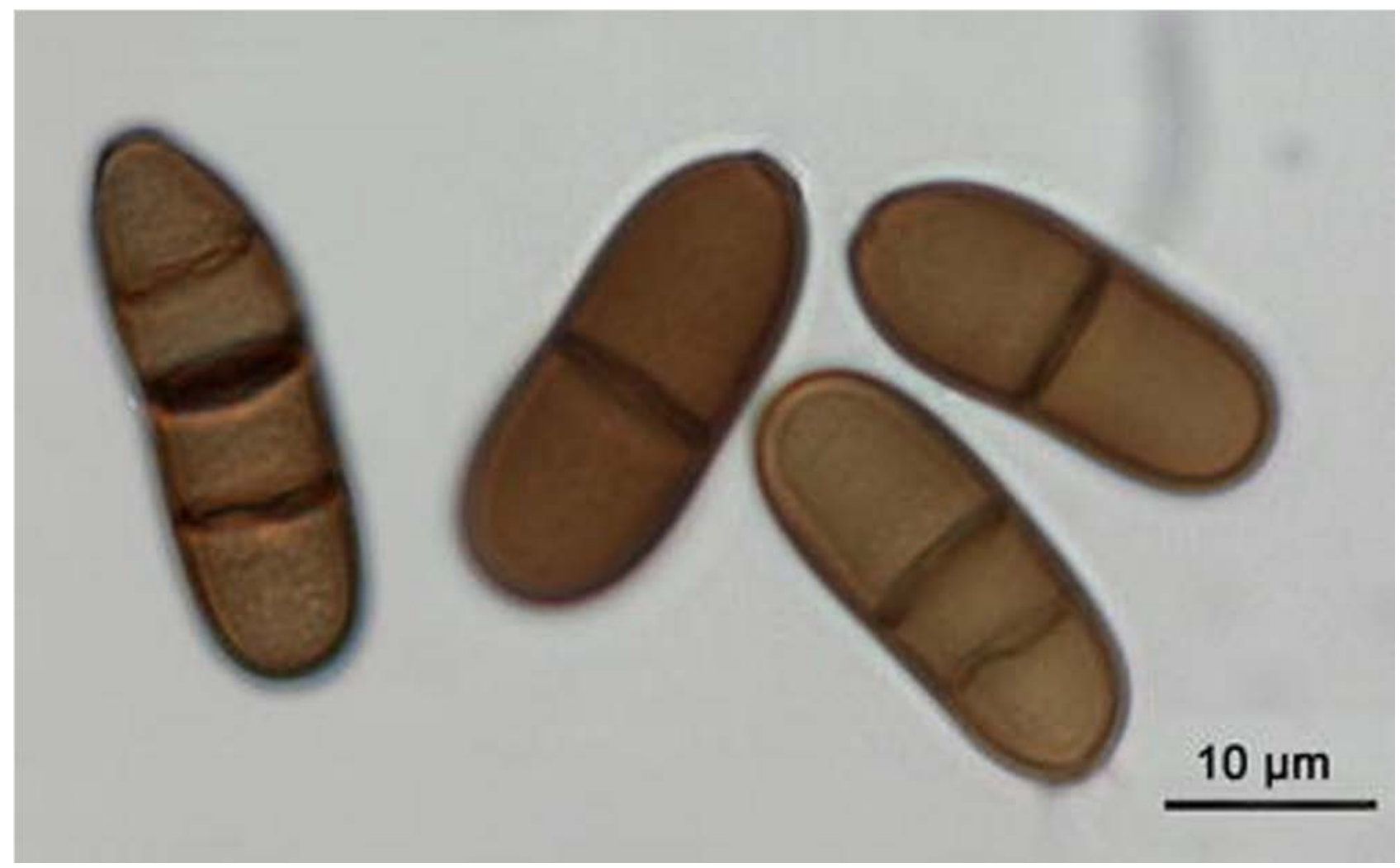

Fig. 2. Dothiorella sp. "C". Conidia with one to three septa.

Seven of the isolates obtained during this study form a subclade within the genus Dothiorella (Fig. 1) and most probably represent a new species. These isolates were designated as Dothiorella sp. "A". Conidia from these isolates were $20.9 \times 9.8 \mu \mathrm{m}$ large (average of 350 conidia) and had one to three septa (Fig. 3). 


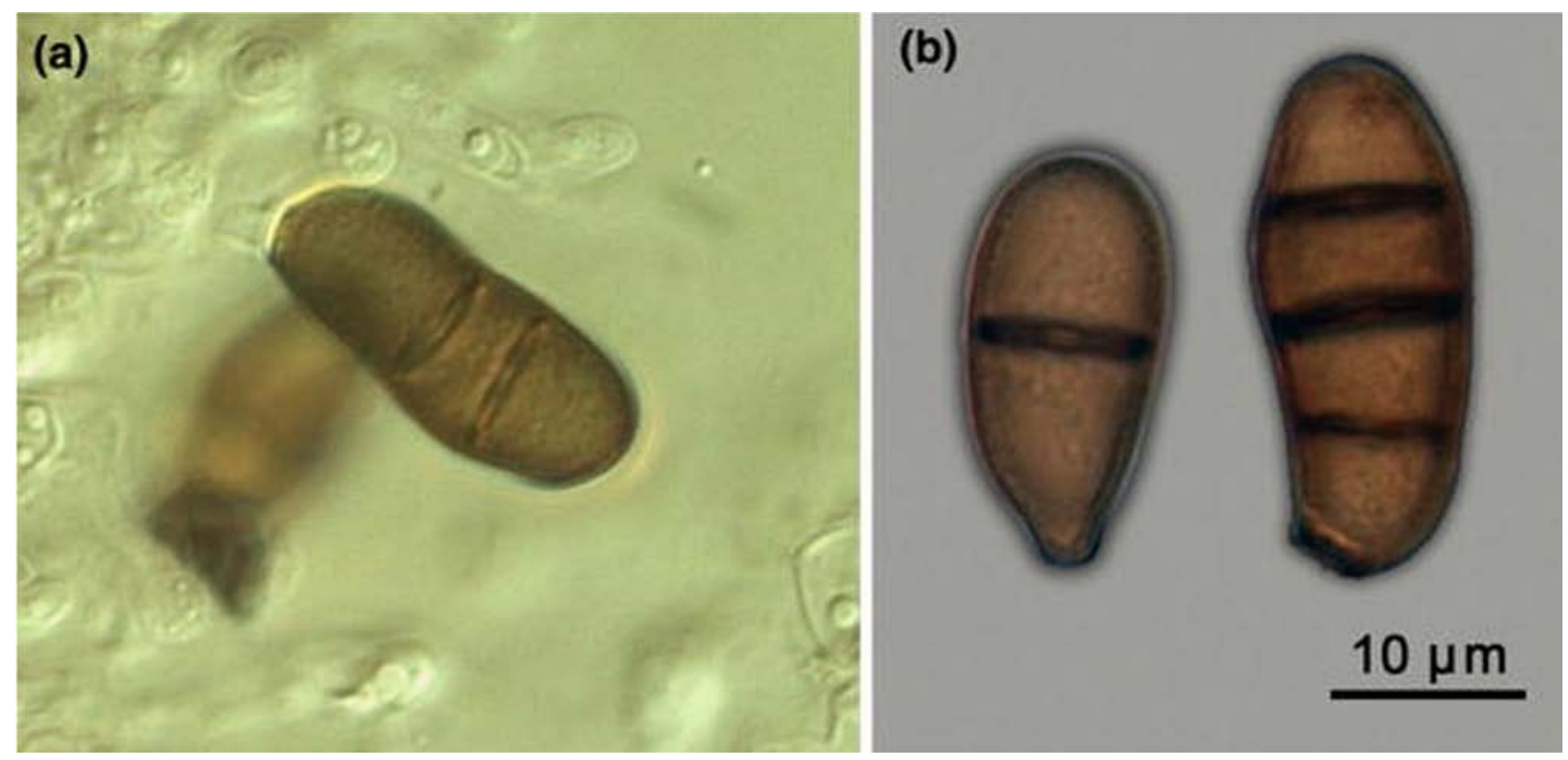

Fig. 3. Dothiorella sp. "A". (a) Developing conidia and conidiogenous cells. (b) Conidia with one to three septa

One isolate, CMW 25743, showed a different PCR-RFLP profile to the other isolates included in this research and grouped with Diplodia coryli Fuckel and Diplodia juglandis Fr. in the phylogenetic tree (Fig. 1); it was designated as Dothiorella sp. "B". The isolate failed to sporulate, as was also reported for the D. coryli and D. juglandis (Phillips et al. 2008).

\section{AFLP analyses}

Three primer combinations, selected to screen the genetic diversity of $50 \mathrm{~B}$. dothidea isolates, yielded a total of 74 visible and polymorphic AFLP bands.

Clustering analysis revealed two groups of isolates (Fig. 4). The larger group included the majority of $B$. dothidea isolates (48), isolated throughout the Kras region in Slovenia and Italy from asymptomatic and diseased $O$. carpinifolia and other hosts. Within this group, further groupings are evident. Isolates from C. coggrygria and A. platanoides, except for APK 4/2 (CMW 25689), were grouped together. Isolates from $O$. carpinifolia were dispersed into different subgroups with no clear lineage linked to the locality or origin of isolation (plant tissue, symptomatic/asymptomatic). The other group included only two isolates, one isolated from a perithecium found on dead bark of $O$. carpinifolia in Opatje Selo, Slovenia and the other obtained from green bark of asymptomatic $O$. carpinifolia in Ravnje, Slovenia.

\section{Pathogenicity}

All isolates tested for pathogenicity on the O. carpinifolia cuttings produced bark lesions within four weeks, and the inoculated fungi were successfully re-isolated from selected inoculated cuttings. No lesions developed on control cuttings inoculated with sterile MEA plugs, and no Botryosphaeriaceae were obtained from these control inoculations.

At the beginning of experiments, the mean relative turgidity of the bark samples was $84.0 \% \pm 0.5 \%$ for the "dry" experiment and $84.0 \% \pm 0.6 \%$ for the "humid" experiment (at the $95 \%$ confidence level). The relative turgidity of the bark was significantly lower at the end of the dry experiment $(76.1 \% \pm 0.8 \%)$, indicating a successful lowering of the bark moisture and thereby causing water stress to the inoculated cuttings. In the "humid" experiment, higher final moisture levels were established $(85.0 \% \pm 0.6 \%)$ compared to the moisture levels at the start of the trial. 


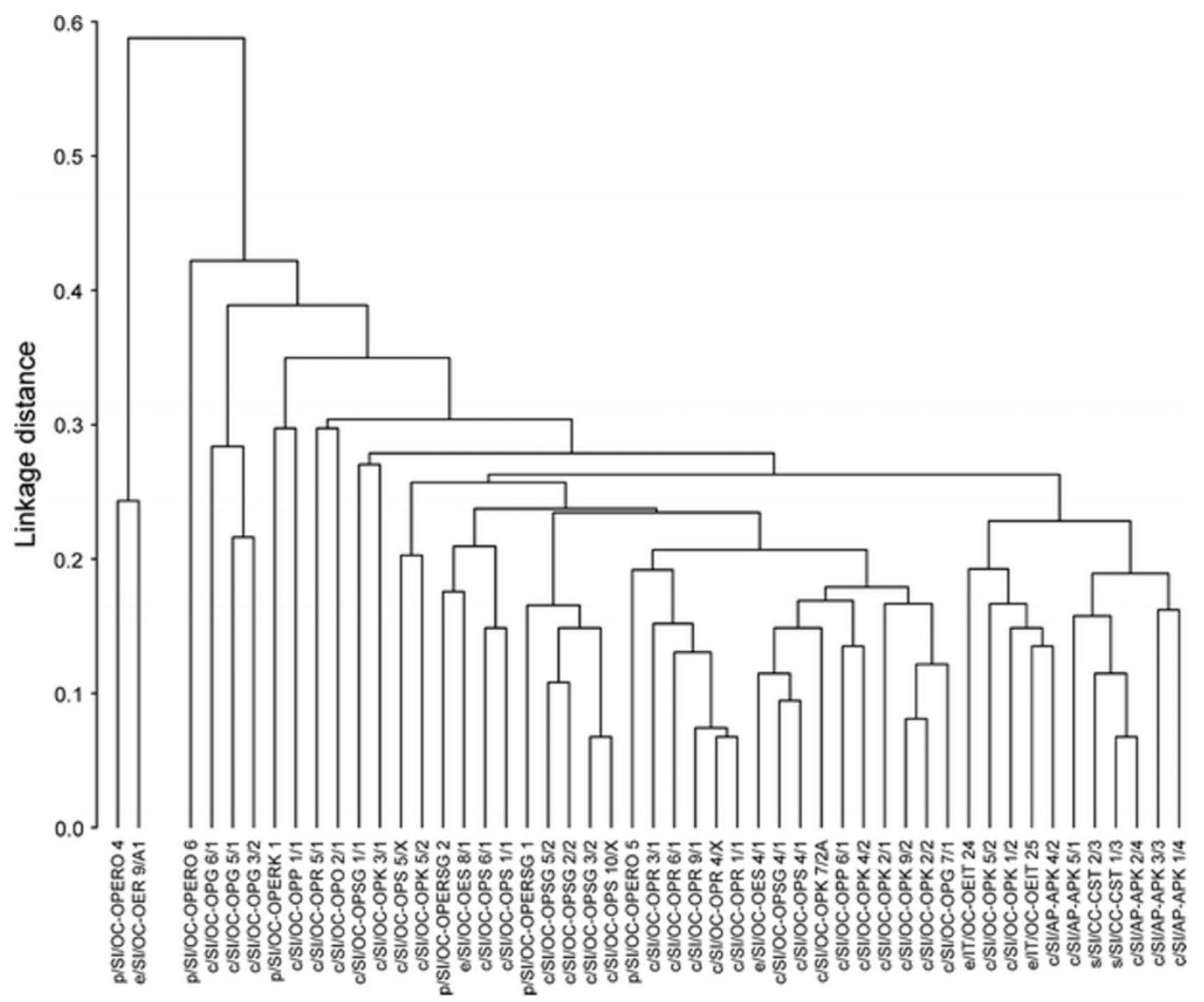

Fig. 4. Unweighted pair-group average (UPGMA) dendrogram based on 50 Botryosphaeria dothidea isolates and 74 AFLP polymorphic markers. Isolates are marked with their original designations (Table 1) to emphasize their origins. Abbreviations before isolate names denote the isolation material ( $\mathrm{p}$, perithecium from dead bark; c, canker-necrotized bark; e, green bark), country (SI, Slovenia; IT, Italy) and host (OC, Ostrya carpinifolia; AP, Acer platanoides; CC, Cotinus coggygria).

In both pathogenicity experiments, there was a great variation in the size of the lesions produced by individual isolates (Fig. 5a, b). The mean lesion lengths for the B. dothidea isolates differed significantly from the control, except for isolate CMW 25696 in the "humid" experiment (Fig. 5b). The comparison between the results of the "humid" and "dry" experiments showed that lower relative bark turgidity generally results in longer lesions.

In both pathogenicity experiments, the isolates of $B$. dothidea produced extensive lesions and displayed higher levels of pathogenicity on $O$. carpinifolia cuttings than those of Dothiorella spp. (Fig. 5a, b). The Dothiorella spp. included in the pathogenicity trials produced lesions that were not statistically different from those of the uninoculated control, even though they were able to infect and cause lesions.

A t-test indicated that the mean lesion lengths produced by $B$. dothidea isolate were not significantly different to those of the corresponding inoculated combination with Dothiorella-like isolates in either the "dry" (Fig. 5a) or the "humid" experiment (Fig. 5b). Thus, there was no evidence of synergistic or antagonistic impacts of Dothiorella isolates on the pathogenic activity of 
B. dothidea.
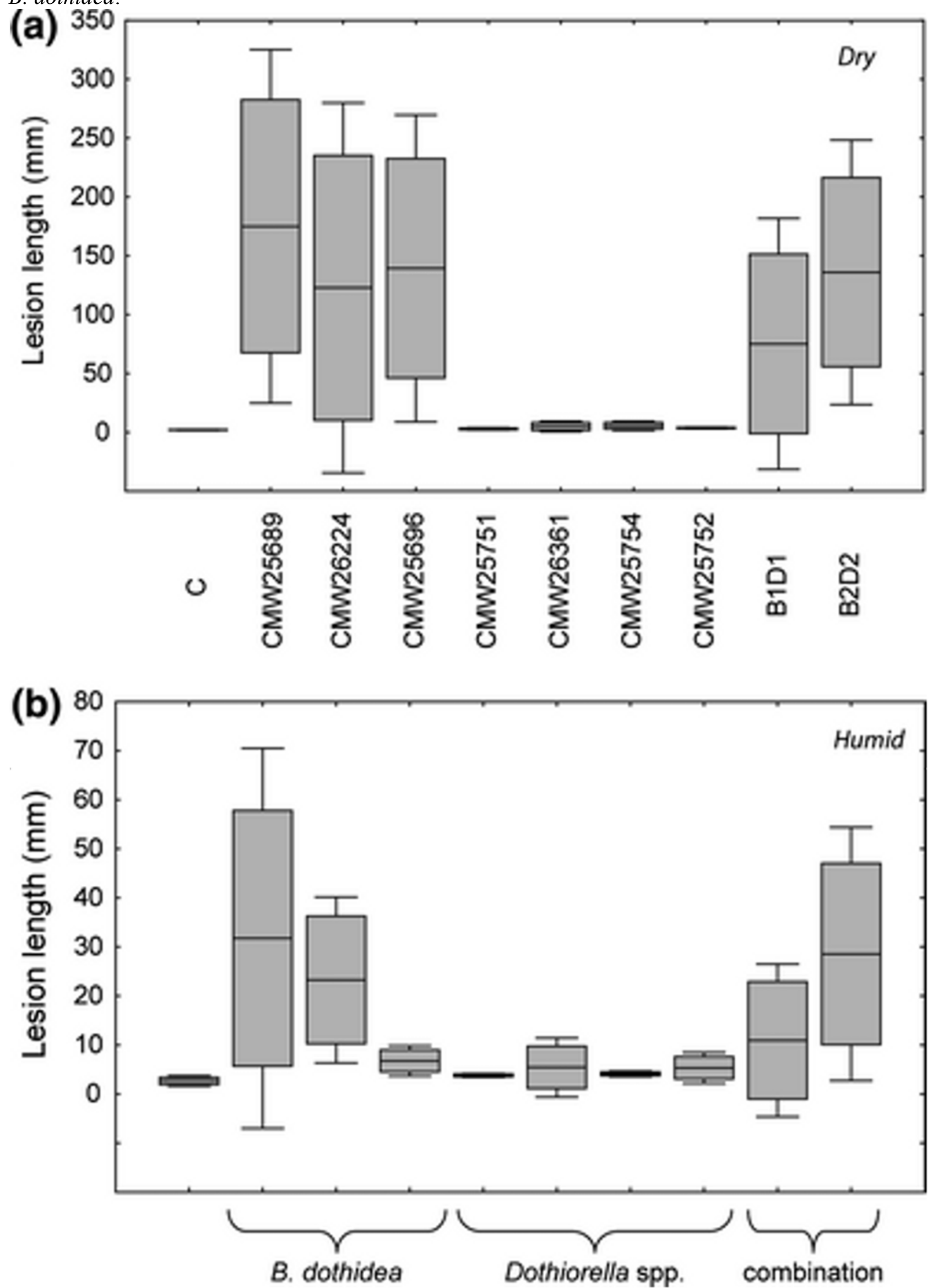

Fig. 5. Mean lesion lengths ( $\mathrm{mm})$ and 95\% confidence intervals for each isolate of different species of Botryosphaeriaceae 4 weeks after inoculations on Ostrya carpinifolia cuttings at (a) dry experiment and (b) humid experiment. Control (C); Botryosphaeria dothidea (CMW 25689, CMW 
25696, CMW 26224); Dothiorella sp. “A” (CMW 25751, CMW 25754, CMW 26361); Dothiorella sp. "C" (CMW 25752); B1D1 = combination of CMW $25696 \times$ CMW 25751, B2D2 = combination of CMW $25689 \times$ CMW 25754

\section{Discussion}

Among the 75 isolates collected from trees grown in autochthonous forests in Slovenia and Italy, different Botryosphaeriaceae species were identified based on ITS rDNA and EF1- $\alpha$ sequence data, PCR-RFLP and anamorph morphology. The majority of the isolates were identified as B. dothidea, while others grouped in the genus Dothiorella. The isolates showed different degrees of pathogenicity on $O$. carpinifolia in laboratory trials, and $B$. dothidea was the most pathogenic of the fungi tested. Insight into the diversity of $B$. dothidea based on AFLP markers revealed a heterogeneous collection of isolates without patterns linked to geographic origin.

Botryosphaeria dothidea was the dominant species isolated from diseased O. carpinifolia trees in Slovenia and Italy. This species was also collected from cankers on $A$. pseudoplatanus trees and from pruned branches of Cotinus coggygria that had been left for few months in the vicinity of the shrub. Observations in the field also revealed branch dieback on Cornus mas L. and Carpinus betulus L., and fungal isolates were determined to be anamorphs of $B$. dothidea (unpublished observations). Botryosphaeria dothidea was also isolated from healthy branches, with no visual signs of disease, on O. carpinifolia both in Italy and Slovenia. Isolates of $B$. dothidea obtained from the same geographic location were dispersed throughout the AFLP marker-based tree. This distribution indicates that a heterogeneous $B$. dothidea population is present in the affected area. Additionally, isolates obtained from the same tree (e.g. CMW 25705 = OPK 2/2 and CMW 26700 = OPK 2/1) did not group close together (Fig. 4), which suggests that a community of various different fungal individuals most likely exists within the same tree and wound. The large number of isolates obtained during the course of this study and reports of $B$. dothidea on other plants (e.g. $A$. pseudoplatanus, Fraxinus excelsior L., Ostrya sp., Platanus spp., Populus nigra L., P. tremula L., Prunus sp., Vitis vinifera L., Quercus rubra L., Q. robur L., Q. suber L., Q. ilex L.) in Europe (Alves et al. 2007; Grasso and Granata 2010; Slippers et al. 2004; Turco et al. 2006; van Niekerk et al. 2004) suggest a wide distribution of the species in this part of the world. Furthermore, the AFLP data from the $B$. dothidea population collected in this study in Slovenia and Italy showed no geographic or tissue-specific lineages, but groupings according to host were revealed. These results, together with the knowledge that $B$. dothidea is common on various native European trees, suggest that $O$. carpinifolia dieback in western Slovenia and northern Italy is associated with a native population of $B$. dothidea.

An isolate obtained from diseased $A$. pseudoplatanus was able to successfully infect $O$. carpinifolia cuttings. This is consistent with previous observations for other members of the Botryosphaeriaceae (Ma et al. 2001a; Pavlic et al. 2007), where cross-infection and movement of $B$. dothidea among different hosts are possible and most likely also occur in affected areas. Different forecasts for the movement of Botryosphaeriaceae between native and introduced hosts and the expansion of hosts susceptible to Botryosphaeriaceae following climate changes have been made (Desprez-Loustau et al. 2006; Pavlic et al. 2007; Slippers and Wingfield 2007). Even though we observed a relatively small range of susceptible hosts in the field, we speculate that further extreme weather conditions will reduce resistance to $B$. dothidea infections and numerous woody host species could be affected.

All three $B$. dothidea isolates tested in this study were able to infect $O$. carpinifolia cuttings in in vitro pathogenicity trials and were successfully re-isolated from lesions. There were significant differences in the pathogenicity of the $B$. dothidea isolates on cuttings with retained moisture content. Interestingly, very low levels of pathogenicity were found for isolate CMW 25696, which originated from necrotic bark. In contrast, isolate CMW 26224, originating from healthy $O$. 
carpinifolia as an endophyte, was pathogenic. Botryosphaeria dothidea isolates analyzed on cuttings subjected to drying did not group into different virulence groups, even though they originated from different hosts and localities and from diseased or asymptomatic tissues. Pathogenicity of isolates collected as endophytes is not unusual and is consistent with the results of previous studies using other species of the Botryosphaeriaceae, recognized as endophytes, saprophytes and latent pathogens (Pavlic et al. 2007; Slippers and Wingfield 2007).

Various studies suggest that global climate change will cause a shift in potential areas and activity of pathogens and also in host susceptibility (Coakley et al. 1999; Desprez-Loustau et al. 2006). Periods of water stress were reported to increase susceptibility of trees to various latent pathogens, for example Diplodia pinea (Desm.) J. Kickx f. (Stanosz et al. 2001) and Biscogniauxia mediterranea (De Not.) Kuntze (Jurc and Ogris 2006; Vannini et al. 1996). Botryosphaeriaceae are known to be latent pathogens, and their pathogenic impact is also predicted to increase under stressrelated conditions, such as those of drought (Crist and Schoeneweiss 1975; Ma et al. 2001b; Slippers and Wingfield 2007). Ma et al. (2001b) have investigated the relationship between water availability and $B$. dothidea growth. They observed that this pathogen grows more rapidly in pistachio leaves under water stress. Our comparison of pathogenicity under humid and dry conditions clearly shows that lowering of the bark water content promotes pathogenicity of $B$. dothidea. As has been suggested elsewhere, stress most likely affects plant resistance to disease development and accelerates the growth of some pathogens (Desprez-Loustau et al. 2006). Bier $(1959,1961,1964)$ showed a close correlation between the development of bark cankers caused by facultative parasites and moisture content of the bark. A correlation between bark moisture and pathogenic activity of tested isolates was also found in this study. The dry conditions in the laboratory experiment imitating drought resulted in extensive lesions and uniformity in expressed pathogenicity in different isolates of $B$. dothidea.

Slovenia and Italy have been confronted with changes in climatic conditions, similar to those also found in other parts of the world. Ostrya carpinifolia dieback caused by species of the Botryosphaeriaceae was unknown until 1997 (Jurc et al. 2006), when the first reports of damages to hop hornbeam appeared. In 2007, European aspen (Populus tremula L.) was reported to be affected by $B$. dothidea in Italy (Grasso and Granata 2010). These reports together with the genetic heterogeneity of the $B$. dothidea population established during this study and the results of pathogenicity tests indicate that an existing pool of native endophytic fungi can become serious pathogens when higher temperatures and drought conditions occur.

A genetically diverse collection of Dothiorella spp. was obtained from O. carpinifolia, $C$. coggygria and J. communis in the affected area. Among the isolates of Dothiorella spp., discrepancies in conidial size and number of septa in conidia were observed. Color and septation were detected in conidia still attached to conidiogenous cells, which is typical for Dothiorella species (Phillips et al. 2005). Isolates were obtained from green bark of O. carpinifolia, dead branches of $C$. coggygria, and the majority of isolates were from necrotized bark of $O$. carpinifolia. Preliminary inoculation experiments with Dothiorella sp. "A" in forests under conditions of extreme drought showed development of extensive bark necroses (unpublished results). Inoculated isolates of Dothiorella spp. on O. carpinifolia cuttings in the pathogenicity tests reported in this study produced lesions not statistically different from those in control inoculations. However, these experiments did show its ability to infect bark and to cause lesions. It is questionable whether these fungi could be defined as potential pathogens. Dothiorella spp. and B. dothidea were isolated consistently from the necrotic bark that developed on the same tree. B. dothidea isolates displayed relatively high levels of pathogenicity on $O$. carpinifolia cuttings. We assume that this fungus has the main role in the disease development. Co-isolations of Dothiorella spp. and B. dothidea from the diseased tissues raise questions about the possible role of Dothiorella in disease development. However, pathogenicity tests with $B$. dothidea in combination with isolates of Dothiorella sp. "A" 
showed no evidence that the latter fungus might inhibit or stimulate the pathogenic activity of $B$. dothidea.

Ostrya carpinifolia dieback has been previously associated with $B$. dothidea, and this research confirms those findings. The disease occurrence is believed to be connected to extreme weather conditions that have provoked endophytic $B$. dothidea population to act pathogenic on stressed trees. The unforeseen disease occurrence and the insight into the diversity of the $B$. dothidea population causing the $O$. carpinifolia dieback follow predictions regarding the influence of global warming on disease occurrence in forest ecosystems.

\section{Acknowledgments}

The study was financed by the Slovenian Research Agency and the Ministry of Agriculture, Forestry and Food of Republic of Slovenia through the research program P4-0107, projects L49585 and V4-0493, and Young Researcher Scheme for B. Piškur. Molecular studies were done in laboratories of the Forestry and Agricultural Biotechnology Institute (FABI) at the University of Pretoria, South Africa and funded by the DST/NRF Centre of Excellence in Tree Health Biotechnology.

\section{Literature Cited}

Alves A, Correia A, Luque J, Phillips A (2004) Botryosphaeria corticola, sp nov on Quercus species, with notes and description of Botryosphaeria stevensii and its anamorph, Diplodia mutila. Mycologia 96:598-613.

Alves A, Correia A, Phillips AJL (2006) Multi-gene genealogies and morphological data support Diplodia cupressi sp nov., previously recognized as D. pinea f. sp. cupressi, as a distinct species.

Fung Div 23:1-15.

Alves A, Phillips AJL, Henriques I, Correia A (2007) Rapid differentiation of species of Botryosphaeriaceae by PCR fingerprinting. Res Microbiol 158:112-121.

Alves A, Crous PW, Correia A, Phillips AJL (2008) Morphological and molecular data reveal cryptic speciation in Lasiodiplodia theobromae. Fung Div 28:1-13.

Bier JE (1959) The relation of bark moisture to the development of canker diseases caused by native, facultative parasites: I. Cryptodiaporthe canker on willow. Can J Bot 37:229-238.

Bier JE (1961) The relation of bark moisture to the development of canker diseases caused by native, facultative parasites: VI. Pathogenicity studies of Hypoxylon pruinatum (Klotzsch) Cke., and Septoria musiva Pk. on species of Acer, Populus, and Salix. Can J Bot 39:1555-1561.

Bier JE (1964) The relation of some bark factors to canker susceptibility. Phytopathology 54:250253.

Burgess TI, Barber PA, Hardy GES (2005) Botryosphaeria spp. associated with eucalypts in Western Australia, including the description of Fusicoccum macroclavatum sp. nov. Australas Plant Path 34:557-567.

Burgess TI, Barber PA, Mohali S, Pegg G, de Beer W, Wingfield MJ (2006) Three new Lasidiplodia spp. from the tropics, recognized based on DNA sequence comparisons and 
morphology. Mycologia 98:423-435.

Coakley SM, Scherm H, Chakraborty S (1999) Climate change and plant disease management. Annu Rev Phytopathol 37:399-426.

Crist CR, Schoeneweiss DF (1975) The influence of controlled stresses on susceptibility of European white birch stems to attack by Botryosphaeria dothidea. Phytopathology 65:369-373.

Crous PW, Slippers B, Wingfield MJ, Rheeder J, Marasas WFO, Philips AJL, Alves A, Burgess T, Barber P, Groenewald JZ (2006) Phylogenetic lineages in the Botryosphaeriaceae. Stud Mycol 55:235-253.

De Vos L, Myburg AA, Wingfield MJ, Desjardins AE, Gordon TR, Wingfield BD (2007) Complete genetic linkage maps from an interspecific cross between Fusarium circinatum and Fusarium subglutinans. Fungal Genet Biol 44:701-714.

Denman S, Crous PW, Taylor JE, Kang JC, Pascoe I, Wingfield MJ (2000) An overview of the taxonomic history of Botryosphaeria, and a re-evaluation of its anamorphs based on morphology and ITS rDNA phylogeny. Stud Mycol 45:129-140.

Desprez-Loustau ML, Marcais B, Nageleisen LM, Piou D, Vannini A (2006) Interactive effects of drought and pathogens in forest trees. Ann For Sci 63:597-612.

Grasso FM, Granata G (2010) First report of Botryosphaeria dothidea associated with dieback of aspen (Populus tremula) in Italy. New Dis Rep 20.

Jurc D, Ogris N (2006) First reported outbreak of charcoal disease caused by Biscogniauxia mediterranea on Turkey oak in Slovenia. Plant Pathol 55:299.

Jurc D, Ogris N, Grebenc T, Kraigher H (2006) First report of Botryosphaeria dothidea causing bark dieback of European hop hornbeam in Slovenia. Plant Pathol 55:299.

Kotar M, Brus R (1999) Naše drevesne vrste. Slovenska matica, Ljubljana.

Lazzizera C, Frisullo S, Alves A, Phillips AJL (2008) Morphology, phylogeny and pathogenicity of Botryosphaeria and Neofusicoccum species associated with drupe rot of olives in southern Italy. Plant Pathol 57:948-956.

Luque J, Martos S, Phillips AJL (2005) Botryosphaeria viticola sp nov on grapevines: a new species with a Dothiorella anamorph. Mycologia 97:1111-1121.

Ma ZH, Boehm EWA, Luo Y, Michailides TJ (2001a) Population structure of Botryosphaeria dothidea from pistachio and other hosts in California. Phytopathology 91:665-672.

Ma ZH, Morgan DP, Michailides TJ (2001b) Effects of water stress on Botryosphaeria blight of pistachio caused by Botryosphaeria dothidea. Plant Dis 85:745-749.

Mohali S, Slippers B, Wingfield MJ (2006) Two new Fusicoccum species from Acacia and Eucalyptus in Venezuela, based on morphology and DNA sequence data. Mycol Res 110:405-413.

Mohali SR, Slippers B, Wingfield MJ (2007) Identification of Botryosphaeriaceae from Eucalyptus, Acacia and Pinus in Venezuela. Fung Div 25:103-125. 
Myburg AA, Remington DL, O'Malley DM, Sederoff RR, Whetten RW (2001) High-throughput AFLP analysis using infrared dyelabeled primers and an automated DNA sequencer. BioTechniques $30: 348-357$.

Pavlic D, Slippers B, Coutinho TA, Wingfield MJ (2007) Botryosphaeriaceae occurring on native Syzygium cordatum in South Africa and their potential threat to Eucalyptus. Plant Pathol 56:624636.

Pavlic D, Wingfield MJ, Barber P, Slippers B, Hardy GES, Burgess TI (2008) Seven new species of the Botryosphaeriaceae from baobab and other native trees in Western Australia. Mycologia 100:851-866.

Pavlic D, Slippers B, Coutinho TA, Wingfield MJ (2009) Multiple gene genealogies and phenotypic data reveal cryptic species of the Botryosphaeriaceae: a case study on the Neofusicoccum parvum/N. ribis complex. Mol Phylogenet Evol 51:259-268.

Phillips A, Alves A, Correia A, Luque J (2005) Two new species of Botryosphaeria with brown, 1septate ascospores and Dothiorella anamorphs. Mycologia 97:513-529.

Phillips AJL, Oudemans PV, Correia A, Alves A (2006) Characterisation and epitypification of Botryosphaeria corticis, the cause of blueberry cane canker. Fung Div 21:141-155.

Phillips AJL, Alves A, Pennycook SR, Johnston PR, Ramaley A, Akulov A, Crous PW (2008) Resolving the phylogenetic and taxonomic status of dark-spored teleomorph genera in the Botryosphaeriaceae. Persoonia 21:29-55.

Saitou N, Nei M (1987) The neighbor-joining method-a new method for reconstructing phylogenetic trees. Mol Biol Evol 4:406-425.

Sakalidis M (2004) Resolving the Botryosphaeria ribis-B. parva species complex; a molecular and phenotypic investigation. School of Biological Sciences and Biotechnology, Murdoch University, Western Australia.

Salvadori C, Maresi G, Barbiero R (2002) Stato fitosanitario delle foreste trentine Anno 2001. Provincia Autonoma di Trento, Instituto Agrario di San Michele all'Adige, Trento.

Slippers B, Wingfield MJ (2007) Botryosphaeriaceae as endophytes and latent pathogens of woody plants: diversity, ecology and impact. Fung Biol Rev 21:90-106.

Slippers B, Crous PW, Denman S, Coutinho TA, Wingfield BD, Wingfield MJ (2004) Combined multiple gene genealogies and phenotypic characters differentiate several species previously identified as Botryosphaeria dothidea. Mycologia 96:83-101.

Slippers B, Johnson GI, Crous PW, Coutinho TA, Wingfield BD, Wingfield MJ (2005a) Phylogenetic and morphological reevaluation of the Botryosphaeria species causing diseases of Mangifera indica. Mycologia 97:99-110.

Slippers B, Summerell BA, Crous PW, Coutinho TA, Wingfield BD, Wingfield MJ (2005b) Preliminary studies on Botryosphaeria species from Southern Hemisphere conifers in Australasia and South Africa. Australas Plant Path 34:213-220.

Slippers B, Smit WA, Crous PW, Coutinho TA, Wingfield BD, Wingfield MJ (2007) Taxonomy, 
phylogeny and identification of Botryosphaeriaceae associated with pome and stone fruit trees in South Africa and other regions of the world. Plant Pathol 56:128-139.

Stanosz GR, Blodgett JT, Smith DR, Kruger EL (2001) Water stress and Sphaeropsis sapinea as a latent pathogen of red pine seedlings. New Phytol 149:531-538.

Swart WJ, Wingfield MJ (1991) Biology and control of Sphaeropsis sapinea on Pinus species in South Africa. Plant Dis 75:761-766.

Tamura K, Dudley J, Nei M, Kumar S (2007) MEGA4: Molecular evolutionary genetics analysis (MEGA) software version 4.0. Mol Biol Evol 24:1596-1599.

Taylor A, Hardy GES, Wood P, Burgess TI (2005) Identification and pathogenicity of Botryosphaeria species associated with grapevine decline inWestern Australia. Australas Plant Path 34:187-195.

Taylor K, Barber PA, Hardy GES, Burgess TI (2009) Botryosphaeriaceae from tuart (Eucalyptus gomphocephala) woodland, including descriptions of four new species. Mycol Res 113:337-353.

Turco E, Marianelli L, Vizzuso C, Ragazzi A, Gini R, Selleri B, Tucci R (2006) First report of Botryosphaeria dothidea on sycamore, red oak, and English oak in northwestern Italy. Plant Dis 90:1106-1106.

van Niekerk JM, Crous PW, Groenewald JZ, Fourie PH, Halleen F (2004) DNA phylogeny, morphology and pathogenicity of Botryosphaeria species on grapevines. Mycologia 96:781-798.

Vannini A, Valentini R, Luisi N (1996) Impact of drought and Hypoxylon mediterraneum on oak decline in the Mediterranean region. Ann Sci For 53:753-760.

Vos P, Hogers R, Bleeker M, Reijans M, Vandelee T, Hornes M, Frijters A, Pot J, Peleman J, Kuiper M, Zabeau M (1995) AFLP - a new technique for DNA-fingerprinting. Nucleic Acids Res 23:4407-4414.

Weatherley PE (1950) Studies in the water relations of the cotton plant: I. The field measurement of water deficits in leaves. New Phytol 49:81-97.

White TJ, Bruns T, Lee S, Taylor J (1990) Amplification and direct sequencing of fungal ribosomal RNA genes for phylogenetics. In: Innis MA, Gelfand DH, Snisky JJ, White TJ (eds) PCR protocols: a guide to methods and applications. Academic Press, San Diego, pp 315-322.

Zafran J, Košiček B, Gasparič B (2006) Spremljanje zdravja gozdnega drevja in razvojne perspektive submediteranskega gozda $=$ Monitoring of health condition of forest trees and the developmental perspective of the sub-mediterranean forest. In: Hladnik D (ed) Monitoring gospodarjenja z gozdom in gozdnato krajino (Studia forestalia Slovenica, No. 127). Biotechnical Faculty, Department of Forestry and Renewable Forest Resources, Ljubljana, pp 207-222. 